\title{
Cancer in populations of African Ancestry: studies of the African Caribbean Cancer Consortium
}

\author{
Camille Ragin ${ }^{1} \cdot$ Elizabeth Blackman $^{1} \cdot$ Robin Roberts $^{2} \cdot$ Raleigh Butler $^{2}$. \\ Samuel Gathere $^{3} \cdot$ Darron Halliday $^{2} \cdot$ Kimlin Ashing $^{4}$
}

Published online: 30 October 2017

(c) Springer International Publishing AG 2017

\begin{abstract}
Among all non-communicable diseases, cancer is the second cause of death worldwide. Although some cancers are preventable [1-3] and treatable and even curable, cancer remains the most common cause of death among populations of African Ancestry worldwide [4,5]. Despite the availability of effective: (1) low-cost early screening techniques for some cancers such as cervical, colon, and prostate and (2) vaccines for 11-26-year-old boys and girls to prevent HPV infection-efforts to address US and global cancer prevention and control in populations of African Ancestry remain a challenge [6-10]. To begin to document this public health crisis in the Caribbean, Latin America, and Africa, the scientific scope of this Special Issue spans molecular epidemiology, prevention, screening, and treatment of cancer in populations of African Ancestry. The studies represent the ongoing research of members of an international collaborative consortium: the African Caribbean Cancer Consortium (AC3) [11-14]. AC3 is supported by the Epidemiology and Genomics Research Program (EGRP) in NCI's Division of Cancer Control and Population Sciences (DCCPS). Over the
\end{abstract}

Camille Ragin, Elizabeth Blackman, Robin Roberts, Raleigh Butler, Samuel Gathere, Darron Halliday, and Kimlin AshingAfrican Caribbean Cancer Consortium.

Camille Ragin

Camille.Ragin@fccc.edu

1 Cancer Prevention and Control Program Fox Chase Cancer Center - Temple Health, Philadelphia, PA, USA

2 School of Clinical Medicine and Research, University of the West Indies, Nassau, Bahamas

3 Kenya Medical Research Institute, Nairobi, Kenya

4 Center of Community Alliance for Research \& Education, Division of Health Equity, City of Hope Medical Center, Duarte, CA, USA past 10 years, the $\mathrm{AC} 3$ has built a network of collaborations that is multidisciplinary including Epidemiology, Medicine, Molecular biology, Genetics/Genomics, Behavioral Science, Community Health Science, Cancer Registration, and Advocacy. The goal being to promote collaboration to address cancer in the African Diaspora. Of the 83 collaborative papers to date, the major scientific themes include cancer surveillance (20\%), genetics/genomics (16\%), HPV studies (18\%), cancer screening (11\%), and the remaining include review articles, social and behavioral research, basic science, and other biomarker research. By geographic region, published work generated from our research involve primarily US-Caribbean collaborations and to a lesser extent US-Caribbean-Africa collaborations.

\section{Screening and cancer control, trends of cancer incidence and mortality}

Cancer prevention and control lies in the realm of both improving screening facilities with timely access and efficient reporting as well as behavioral science to increase screening utilization, adherence to medical care, and enhanced prevention practices including HPV vaccine uptake via community engagement. In the United States, cancer incidence and mortality rates for most cancers are declining, even for African Americans (with the exception of breast cancer in African American women) [15] and is likely attributed to improvements in cancer control programs and screening rates for certain cancers. However, the disparity in incidence and mortality remains, and higher rates are still observed for African Americans in comparison to other US racial/ethnic groups [16]. In contrast, the burden of cancer is rising in Sub-Saharan Africa and cancer control programs, resources for treatment, and early detection of cancer are 
not sufficient to address this need [17]. In this Special Issue, cancer control programs were examined by Franklin et al. for countries that comprise the Caribbean community (CARI$\mathrm{COM}$ ), (i.e., Caribbean islands and Caribbean countries located on the Latin American continent where more than $80 \%$ of populations are of African Descent). Similar to SubSaharan African countries, cancer control programs in the Caribbean are at different stages of development and are not adequately addressing the high mortality rates observed in these African-descent populations. This is also underscored by Thomas-Purcell et al. who reports a similar perspective from in-depth interviews of gatekeepers responsible for cancer prevention and cancer care services. The merits of the PAP test in cervical cancer care are undisputable and while much controversy remains to benefits of screening test campaigns in both breast and prostate cancers, the benefits of cancer awareness and positive health-seeking behaviors cannot be ignored. These successes are yet to be duplicated in populations of African ancestry, even in the developed countries. Lack of awareness of cancer risk factors and positive health-seeking remain a constant theme. Addressing these social determinants of health is not insurmountable. Low-cost screening programs with voluntarism and advocacy can action the social determinants of health to close the health equity gap.

\section{Treatment outcomes}

Many new and improved treatment modalities have emerged in the PSA era aligned with the increasing incidence of prostate cancer. Unfortunately, for many low-resource countries, these are prohibitive. Where these advanced treatments are available, however, it is incumbent on the health care providers to show that the outcomes match international standards and even in the face of low volume facilities. Equally, lowresource countries must meet the challenges to define local treatment that reflects local cultural practices and their possible benefits. We are forever reminded of the many major drug discoveries that were rooted in local herbal medicinal practices.

Access and availability of cancer treatment continue to be a key contributor to the disproportionate burden of cancer in populations of African Ancestry. Delays in the time from diagnosis to cancer treatment is a key factor attributing to lower survival rates $[18,19]$. In this Special Issue, Jones et al. report for the first time examinations of waiting time from diagnosis to cancer treatment in the Bahamas and shows improvements for cervical cancer from 78 to 65 days over the decade 2006-2016. In the same setting, when accounting for risk-stratification, prostate cancer outcomes for Caribbean men diagnosed in the Bahamas with non-metastatic cancer were comparable in treatment and had similar outcomes to developed countries. The article suggests that at least for prostate cancer, the poor survival rates observed in Black men from the Caribbean may be improved with standardization or comparable treatment strategies. There is a need for further research that more carefully examines treatment and patient outcomes in these populations in order to improve and optimize the delivery of cancer treatment in these populations.

\section{Cancer risk factors}

Cancer care is expensive. The need to apply the adage that an ounce of prevention is worth a pound of cure has never been more applicable. National strategic objectives in populations of African ancestry must be driven by the need for disease prevention and wherever and whenever possible, to early detection and treatment. Vaccination for cervical cancer provides the promise of bypassing the expensive path of treating clinical disease, which in developing countries translates to advance disease care, the most expensive presentation. To recoup these benefits of early detection and prevention, there is a need to delineate the biomarkers that truly reflect the disease variant in populations of African Ancestry, in all cancers.

Established risk factors that contribute to the disproportionate burden of cancer in African Diaspora populations have been documented in the literature. The majority of studies suggest that this disparity is primarily attributed to low socioeconomic status and poor access or utilization of cancer screening and treatment. A focus on biological contribution to cancer disparities has been less studied. Here in this Special Issue, Bassey-Archibong et al. suggest implications of African ancestry in the development of triplenegative breast cancer. Kaiso, a biomarker known to be correlated with aggressiveness of triple-negative breast cancer was examined in breast cancer tissues from Caucasian, African American, Caribbean, and African women. This US-Caribbean-Africa comparison shows higher expression of Kaiso in the women of African descent in comparison to Caucasian women. Thus, another example that supports the biological underpinnings of cancer disparities. More research focused on comparative studies between populations of African ancestry is needed.

\section{Summary}

The AC3 contributors to this Special Issue present scientific achievements and milestones in collaborative cancer research. Articles span topics in areas of screening and cancer control, cancer surveillance (trends in incidence and mortality), treatment outcomes, and cancer risk factors 
in the African Diaspora. As editors, we underscore the undue burden of cancer among peoples of the African Diaspora. People of African Ancestry living in the US and Europe have the highest overall cancer incidence and mortality compared to other racial/ethnic groups [16]. Similarly, people of African ancestry in the Caribbean and Latin American experience some of the highest cancer incidence and mortality worldwide [20, 21]. Additionally, Africans in Africa suffer the greatest cancer-related mortality in the world [20,22]. Emerging evidence suggests multilevel factors associated with poorer outcomes including genetics, inherited precocious oncogenes, epigenetics, environmental carcinogen, and behavioral factors. Newer studies are now pointing to the oncogenic role of society including poverty, marginalized social status, and healthcare systems and providers including disparate access to and quality of care.

Yet, we are hopeful that this Special Issue will attract much needed attention to the cancer plight of peoples of African ancestry. Addressing the African ancestry oncogenic phenomenon-more aggressive with successful metastatic features-may provide novel keys to the cancer cure for all. Our AC3 leaders have identified practical research opportunities including use of mobile technology, the urgency of primary prevention practices including healthful, plantbased eating, reducing sugars and animal fats, and uptake of $\mathrm{HBV}$ and HPV vaccines.

Many Caribbean and African nations have yet to establish national cancer registries. The dictum that you can't manage what you can't measure is the proverbial message in reporting national cancer incidences and mortalities in these regions. The articles in this Special Issue identify the need to document occurrence, treatment, and outcomes to provide reliable data and direct targeted interventions; national as opposed to hospital-based cancer registries remains a major hurdle. In some instances, the ethnicity reflect low prevalence and possibly different cancer biology. In low-resource countries, prudence is paramount and data accuracy cannot be overemphasized.

Clearly, more global industry/private and government/ public partnership funding are required. Also critically important is the training and grooming of researchers who are well prepared with access to adequate facilities to conduct rigorous science, clinicians who provide the best available timely treatments delivered with care, policy makers who will take up the call for population health and quality care, and advocates readied to lead in creating and protecting healthy communities. The disparate cancer landscape of the African Diaspora warrants urgent scientific studies with actionable, translational deliverables into clinical and community practice. This action to solution approach necessitates increased, team science with clinicians, policy makers, and advocate-engaged collaborations.
In the new millennium, cancer has emerged as a leading cause of mortality and morbidity in Low Middle Income countries (LMIC), particularly in countries with populations that are predominantly of African descent. The major advances in curbing the disease burden attained through screening, health prevention and promotion, screening, diagnosis, and treatment have eluded most LMIC and technological advances. AC3 has embraced the WHO challenge to curb the high cancer burden by closing the health inequity gap through action on pertinent and relevant social determinants of health. Through our collaborative bench research and population-based initiatives, AC3 seeks to define our genetic risk factors, better the awareness and educational programs, and with emphasis on earlier detection and treatment, improve the health experience and outcomes in our populations of African ancestry. In the first 10 years of our existence, we defined our values and mission and we established and fortified our linkages. This supplement highlights our accomplishments. Thanks to funding from the NIH and the partnerships that AC3 has cemented at the national, regional and national levels, we look forward to advance the health of people of African ancestry in the next decade, and with great optimism.

\section{References}

1. Villa LL, Costa RL, Petta CA, Andrade RP, Ault KA, Giuliano AR, Wheeler CM, Koutsky LA, Malm C, Lehtinen M, Skjeldestad FE, Olsson SE, Steinwall M, Brown DR, Kurman RJ, Ronnett BM, Stoler MH, Ferenczy A, Harper DM, Tamms GM, Yu J, Lupinacci L, Railkar R, Taddeo FJ, Jansen KU, Esser MT, Sings HL, Saah AJ, Barr E (2005) Prophylactic quadrivalent human papillomavirus (types 6,11,16, and 18) L1 virus-like particle vaccine in young women: a randomised double-blind placebo-controlled multicentre phase II efficacy trial. Lancet Oncol 6(5):271-278

2. Harper DM, Franco EL, Wheeler C, Ferris DG, Jenkins D, Schuind A, Zahaf T, Innis B, Naud P, De Carvalho NS, Roteli-Martins CM, Teixeira J, Blatter MM, Korn AP, Quint W, Dubin G (2004) Efficacy of a bivalent L1 virus-like particle vaccine in prevention of infection with human papillomavirus types 16 and 18 in young women: a randomised controlled trial. Lancet 364:1757-1765

3. Ronco G, Giorgi-Rossi P, Carozzi F, Confortini M, Dalla PP, Del MA, Ghiringhello B, Girlando S, Gillio-Tos A, De ML, Naldoni C, Pierotti P, Rizzolo R, Schincaglia P, Zorzi M, Zappa M, Segnan N, Cuzick J (2010) Efficacy of human papillomavirus testing for the detection of invasive cervical cancers and cervical intraepithelial neoplasia: a randomised controlled trial. Lancet Oncol 11(3):249-257

4. American Cancer Society (2016) Cancer facts \& figures for African Americans 2016-2018. Atlanta: American Cancer Society

5. American Cancer Society (2014) Regional diversity, cancer in Sub-Saharan Africa. In: The cancer atlas. Atlanta: American Cancer Society

6. Anderson T, Wallace T, Aung M, Jolly PE (2015) Prostate cancer knowledge, attitudes and screening practices among men in Western Jamaica. West Indian Med J 65(1):67-77 
7. Emtage JB, Poch MA, Hutton MT, Emtage JB (2015) Prostate cancer trends in Barbados: an analysis of the Barbados Urologic Diseases Survey database. Cancer Epidemiol 39(6):825-830

8. Romaguera J, Seymour S, Cabrera V, Medina J, De JE, Ortiz AP (2015) Use of screening tests for colorectal cancer among gynecologists in Puerto Rico. Bol Asoc Med PR 107(2):82-85

9. Randall TC, Salicrup LA, Luciani S, Trimble EL (2015) HPV testing in resource-limited settings: how can we reach the next level of cervical cancer screening in Latin America and the Caribbean? Oncologist 20(10):1101-1104

10. Bond SM, Cartmell KB, Lopez CM, Ford ME, Brandt HM, Gore EI, Zapka JG, Alberg AJ (2016) Racial and ethnic group knowledge, perceptions and behaviors about human papillomavirus, human papillomavirus vaccination, and cervical cancer among adolescent females. J Pediatr Adolesc Gynecol 29(5):429-435

11. Blackman E, Campbell J, Bowen C, Delmoor E, Jean-Louis G, Noumbissi R, OGarro Y, Richards-Waritay O, Straughter S, Tolbert V, Wilson B, Ragin C (2014) The 4th bi-annual international African-Caribbean Cancer Consortium conference: building capacity to address cancer health disparities in populations of African descent. Infect Agents Cancer 9:35

12. Ragin C, Taioli E (2009) The Second International AfricanCaribbean Cancer Consortium for the study of viral, genetic and environmental cancer risk factors. Infect Agents Cancer 4(Suppl 1):S1

13. Ragin C, Campbell J (2010) Building capacity to address cancer health disparities in populations of African descent: establishing international networks and successful collaborations

14. Ragin CC, Taioli E, McFarlane-Anderson N, Avery G, Bennett F, Bovell-Benjamin A, Brown TA, Carrington A, Campbell-Everett L, Ford J, Hennis A, Jackson M, Lake S, Leske MC, Magai C, Nemesure B, Neugut A, Odedina F, Okobia M, Patrick A, Best PW, Reams RR, Roberts R, Scott-Hastings S, Sharma S, Wheeler
V, Wu SY, Bunker C (2007) African-Caribbean cancer consortium for the study of viral, genetic and environmental cancer risk factors. Infect Agents Cancer 2(1):17-22

15. Jemal A, Ward EM, Johnson CJ, Cronin KA, Ma J, Ryerson B, Mariotto A, Lake AJ, Wilson R, Sherman RL, Anderson RN, Henley SJ, Kohler BA, Penberthy L, Feuer EJ, Weir HK (2017) Annual Report to the Nation on the status of cancer, 1975-2014, featuring survival. J Natl Cancer Inst 109(9):1290-1314

16. Howlader N, Noone AM, Krapcho M, Miller D, Bishop K, Kosary CL, Yu M, Ruhl J, Tatalovich Z, Mariotto A et al (ed) SEER Cancer Statistics Review, 1975-2014, National Cancer Institute, Bethesda, MD, based on November 2016 SEER data submission, posted to the SEER web site, April 2017

17. Stefan DC (2015) Cancer care in Africa: an overview of resources. J Glob Oncol 1(1):30-36

18. Ashing-Giwa KT, Gonzalez P, Lim JW, Chung C, Paz B, Somlo G, Wakabayashi MT (2010) Diagnostic and therapeutic delays among a multiethnic sample of breast and cervical cancer survivors. Cancer 116(13):3195-3204

19. Lim JW, Ashing-Giwa KT (2011) Examining the effect of minority status and neighborhood characteristics on cervical cancer survival outcomes. Gynecol Oncol 121(1):87-93

20. Ferlay J, Parkin DM, Curado MP, Bray F, Edwards B, Shin HR, Forman D (2010) Cancer incidence in five continents, volumes I to IX: IARC CancerBase No. 9 [Internet] International Agency for Research on Cancer. Available from http://ci5.iarc.fr

21. Razzaghi H, Quesnel-Crooks S, Sherman R, Joseph R, Kohler B, Andall-Brereton G, Ivey MA, Edwards BK, Mery L, Gawryszewski V, Saraiya M (2016) Leading causes of cancer mortalityCaribbean region, 2003-2013. MMWR Morb Mortal Wkly Rep 65(49):1395-1400

22. American Cancer Society (2011) Cancer in Africa. Atlanta: American Cancer Society 